\title{
PREPARATION AND CHARACTERIZATION OF TRANSPARENT CONDUCTIVE ZnO THIN FILMS BY DC MAGNETRON SPUTTERING
}

\author{
Sudjatmoko, Suryadi, Widdi Usada, Tono Wibowo, and Wirjoadi \\ Centre for Research and Development of Advanced Technology \\ Jl. Babarsari P.O. Box 6101 Ykbb, Yogyakarta 55281
}

\begin{abstract}
PREPARATION AND CHARACTERIZATION OF TRANSPARENT CONDUCTIVE ZnO THIN FILMS BY DC MAGNETRON SPUTTERING. Transparent and conductive aluminium-doped zinc oxide thin films have been prepared by dc magnetron sputtering using targets composed of $\mathrm{ZnO}$ and $\mathrm{Al}_{2} \mathrm{O}_{3}$. Polycrystalline ZnO:Al films were deposited onto a heated glass substrate. The surface morphology and crystalline structure, as well as optical and electrical properties of the deposited films were found to depend directly on substrate temperature. From optical and electrical analysis were observed that the optical transmittance and conductivity of the $\mathrm{ZnO}$ :Al transparent conductive oxide films increased when deposition temperature was raised from 200 to $400{ }^{\circ} \mathrm{C}$. Films grown on $300^{\circ} \mathrm{C}$ substrates showed a high conductivity value of $0.2 \times 10^{2} \Omega^{-1} \mathrm{~cm}^{-1}$ and a visible transmission of about $85 \%$. The growth temperatures of $300{ }^{\circ} \mathrm{C}$, aluminium doping levels of $0.9 \mathrm{wt} . \%$ were preferable to achieve $\mathrm{ZnO}$ :Al films with optical and structural qualities as required for solar cell applications.
\end{abstract}

Keywords : Polycrystalline, Zinc oxide, Morphology, Conductivity, Transmission, X-ray diffraction

\section{INTRODUCTION}

$\mathrm{Z}$ inc oxide $(\mathrm{ZnO})$, a semiconducting, photoconducting, piezoelectric, and optical waveguide material, shows a wide range of scientific and technological applications [1,2]. They have played an important role in various such as surface acoustic wave devices [3,4], varistor $[5,6]$, cantilevers [7,8], thin film gas sensors [9], and as thin film transparent conducting electrodes in solar cells [10,11]. Many methods have been used to prepare $\mathrm{ZnO}$ thin films including chemical vapor deposition, evaporating method, sputtering, spray pyrolysis, and laser ablation [12, 13, 14]. Among these deposition methods the sputtering is considered to be the most favorable because it is possible to obtain highly oriented uniform $\mathrm{ZnO}$ films even on amorphous substrates.

Recently the transparent and conductive oxide (TCO) thin films such as $\mathrm{ZnO}$ with wide band gaps near $3.3 \mathrm{eV}$ have attracted interest as a window material for solar cell and display devices. Krunks et al. [15] reported that $\mathrm{ZnO}$ thin films are prepared by the spray pyrolysis method which is well know for its simplicity, reproducibility and possibility to produce cheap large-area films. In the past few years $\mathrm{ZnO}$ thin films doped with any of the group IIIB elements (Ga, Al, B, or In) have been proposed as transparent electrode materials. Aluminium-doped $\mathrm{ZnO}$ in particular is more chemically (thermally) stable than indium tin oxide (ITO) under hydrogen plasma processes that are commonly used for the production of solar cells and electroluminescent devices. Jin Ma et al. [16] reported the electrical and optical properties of $\mathrm{ZnO}$ :Al films prepared by an evaporation method together with the opto-electrical properties. In this paper, the deposition of $\mathrm{ZnO}: \mathrm{Al}$ films by the dc magnetron sputtering using targets composed of $\mathrm{Al}_{2} \mathrm{O}_{3}$ and $\mathrm{ZnO}$ is investigated. In addition, the effect of impurity doping into the $\mathrm{ZnO}: \mathrm{Al}$ film is 
reported together with the opto-electrical properties.

\section{EXPERIMENT}

$\mathrm{ZnO}$ and $\mathrm{ZnO}: \mathrm{Al}$ thin films were prepared by using dc planar sputtering system with an external solenoid coil. A 60 mm-diam disc of sintered $\mathrm{ZnO}$ powder (purity, 99.98\%) and a sintered disc composed of a mixture of $\mathrm{ZnO}$ powder and $<2.0$ wt $\% \mathrm{Al}_{2} \mathrm{O}_{3}$ (purity, 99.98\%) dopant were used as the target. Sputtering was carried out at a pressure of $8 \times 10^{-2}-1.2 \times$ $10^{-1}$ Torr in pure argon gas with a power of $40 \mathrm{~W}$. A dc magnetic field from the external solenoid coil was varied up to about $200 \mathrm{G}$. The glass substrates were placed parallel to the target surface at a distance of $35 \mathrm{~mm}$. Substrate temperatures were varied from $200{ }^{\circ} \mathrm{C}$ to $400{ }^{\circ} \mathrm{C}$, and the surface temperature of the substrate was monitored by thermocouple and controlled by a heater during the deposition. The electrical resistivity was measured at room temperature by the I-V method, the crystallinity and surface morphology of the films were studied by x-ray diffractrometry and by scanning electron microscopy, respectively. The transmission through the films was measured in the wavelength range of $300-800 \mathrm{~nm}$ by means of a spectrophotometer.

\section{RESULTS AND DISCUSSION}

ZnO:Al films were deposited onto a heated glass substrates in the temperature region from 200 up to $400{ }^{\circ} \mathrm{C}$, and under pure argon gas sputtering pressure of $9 \mathrm{x}$ $10^{-2}$ Torr. Variations of $\mathrm{X}$-ray diffraction patterns of $\mathrm{ZnO}: \mathrm{Al}$ films with $\mathrm{Al} / \mathrm{Zn}=0.9$ at.\% deposited at various substrate temperatures are shown in fig. 1. X-ray analysis indicated that the $\mathrm{ZnO}: \mathrm{Al}$ films deposited at 200, 250 and $300{ }^{\circ} \mathrm{C}$ exhibited the c-axis orientation perpendicular to the substrate surface, as can be seen in fig. 1a, $1 b$, and 1c, respectively. The crystallinity evaluated from the intensity and full width at half-maximum of the (002) diffraction peak improved as the substrate temperature was increased. The sharpening and higher of peak intensity (counts) indicates that the grains are increasing in size.
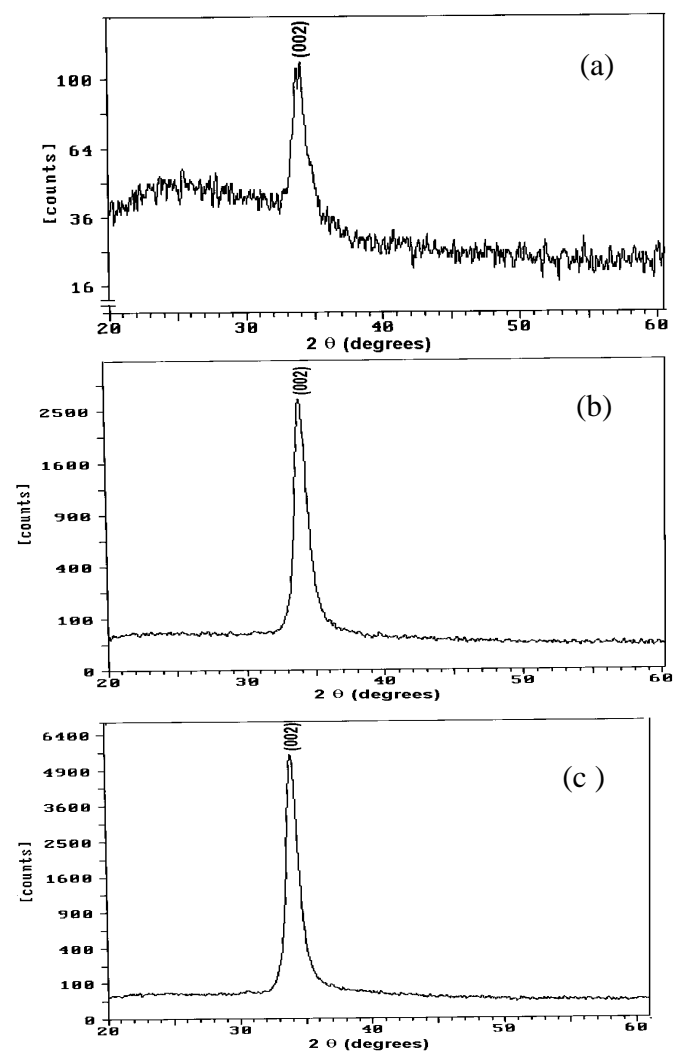

Fig. 1. X-ray diffraction patterns measured on ZnO:Al films deposited at (a) $200{ }^{\circ} \mathrm{C}$, (b) 250

${ }^{\circ} \mathrm{C}$, and (c) $300{ }^{\circ} \mathrm{C}$ substrate temperatures, respectively.

Fig. 2 shows the X-ray diffraction spectra of a $\mathrm{ZnO}$ film and a $\mathrm{ZnO}$ :Al film with $\mathrm{Al} / \mathrm{Zn}=0.9$ at.\%. X-ray diffraction analysis indicates that the deposited films are polycrystalline and oriented perpendicular to the substrate surface, i.e. c-axis orientation. The (002) diffraction peak intensity of the $\mathrm{ZnO}$ :Al film is higher and the half-width is smaller than the $\mathrm{ZnO}$ film, this indicates that the grain size of the 
$\mathrm{ZnO}$ :Al film is larger if compared with the $\mathrm{ZnO}$ film. Crystallographic orientation also correlates with micro-structure as shown in fig. 3. Film deposited at lower temperature $\left(200^{\circ} \mathrm{C}\right)$ shown in fig. 3a. has a homogeneous distribution of small grains yields a uniform and smooth film. The lateral grain size became bigger with increasing substrate temperature (fig. 3b), this is generally caused the increasing surface mobility of the adsorbed species at high substrate temperature [17]. In the films deposited at substrate temperatures above $300{ }^{\circ} \mathrm{C}$, resulting in a smaller grain size (fig. 3c). Note that increasing the kinetic energy of the incident species by increasing the substrate temperature, also increases the surface mobility. However, at sufficiently high kinetic energies, the surface mobility is reduced due to the penetration of the incident species into the substrate, resulting in a smaller grain size.
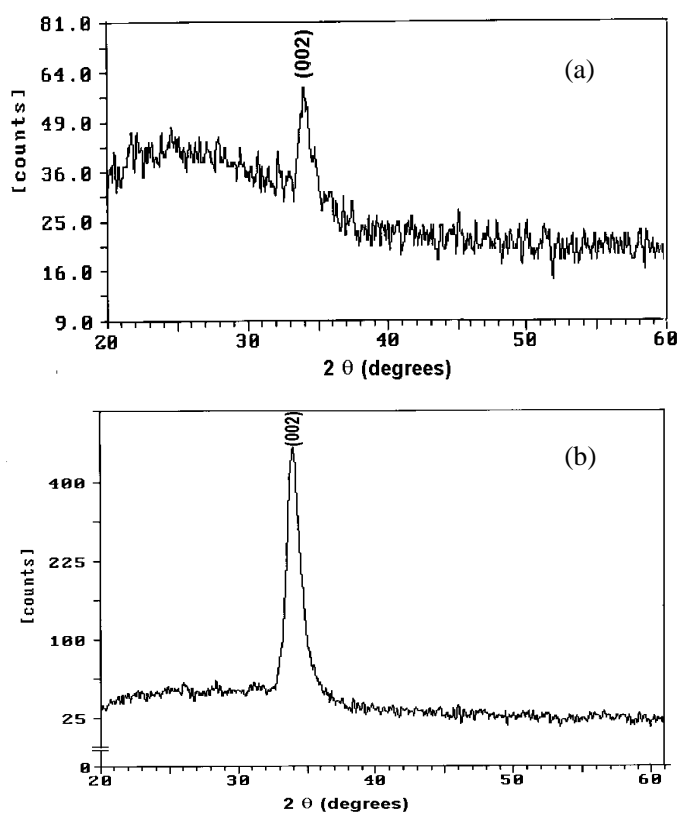

Fig. 2. X-ray diffraction patterns of $\mathrm{ZnO}$ (a), and ZnO:Al films (b), at substrate temperature of 300

${ }^{\circ} \mathrm{C}$ and argon gas pressure of $1 \times 10^{-1}$ Torr.

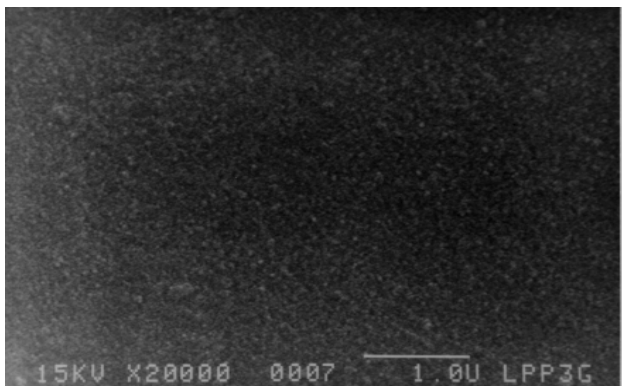

(a)

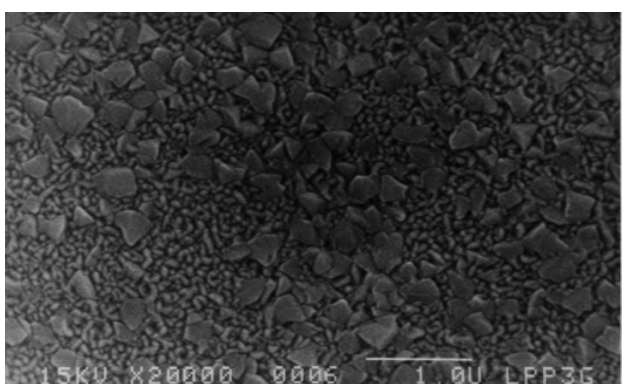

(b)

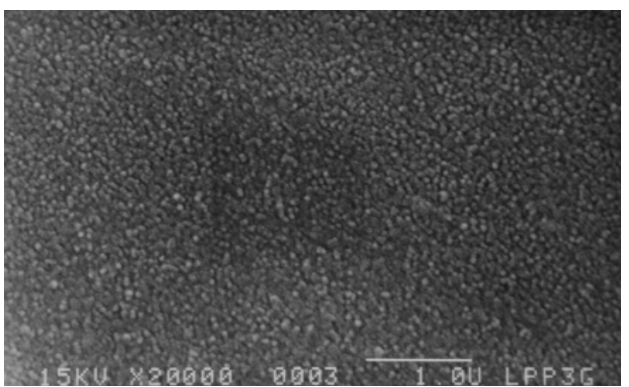

(c)

Fig. 3. SEM micrograph taken on the surface of $\mathrm{ZnO}$ :Al films deposited at (a) $200{ }^{\circ} \mathrm{C}$, (b) $300{ }^{\circ} \mathrm{C}$, and (c) $400{ }^{\circ} \mathrm{C}$.

The electrical conductivity as a function of the substrate temperature is plotted in fig. 4. During the deposition of $\mathrm{ZnO}$ and $\mathrm{ZnO}: \mathrm{Al}$ films, the sputter gas pressure and the dc power were maintained constant, and the $\mathrm{Al} / \mathrm{Zn}$ ratio of the films deposited is about 0.9 at.\%. It can be observed from fig. 4, the electrical conductivity increases with the substrate temperature and reaches a maximum at 300 ${ }^{\circ} \mathrm{C}$. The electrical conductivity of $\mathrm{ZnO}: \mathrm{Al}$ 
films is higher than undoped $\mathrm{ZnO}$ films by about five orders of magnitude, and the highest conductivity of the films is about $0.2 \times 10^{2} \Omega^{-1} \mathrm{~cm}^{-1}$. The electrical conductivity of $\mathrm{ZnO}: \mathrm{Al}$ thin films depend on the $\mathrm{Al} / \mathrm{Zn}$ ratio. The experimental data shows that the electrical conductivity of the $\mathrm{ZnO}: \mathrm{Al}$ film increases rapidly at lower $\mathrm{Al}$ concentrations and reaches a maximum value at $\mathrm{Al} / \mathrm{Zn}=0.9$ at.\%, whereas above $\mathrm{Al} / \mathrm{Zn}=0.9$ at. $\%$ the electrical conductivity decreases with increasing $\mathrm{Al}$ concentration. A similar behaviour was obtained by Jin Ma et al. [16], the ZnO:Al films prepared by an evaporation method. As the $\mathrm{Al}$ dopant concentration is increased, more dopant atoms occupy lattice sites of zinc atoms resulting in more charge carriers. Thus the electrical conductivity of $\mathrm{ZnO}: \mathrm{Al}$ film increases with increasing dopant concentration. However, after a certain doping level the dopant atoms in the crystal grain and grain boundaries tend to saturation, resulting in a decreases in the conductivity of the $\mathrm{ZnO}$ :Al thin films.

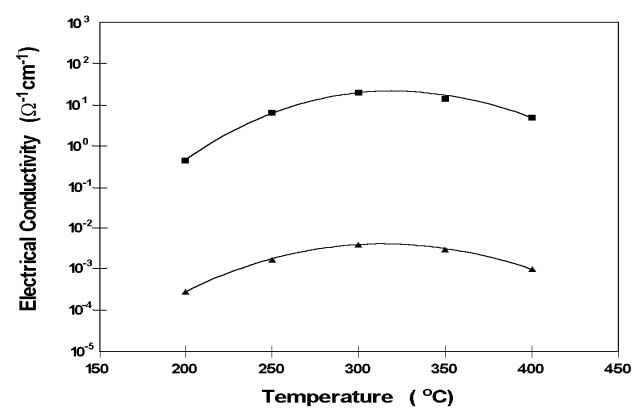

Fig. 4. Electrical conductivity values of $\mathrm{ZnO}$ and $\mathrm{ZnO}$ :Al films as a function of substrate temperature, (a) $\mathrm{ZnO}$ film, and (b) $\mathrm{ZnO}$ :Al film.

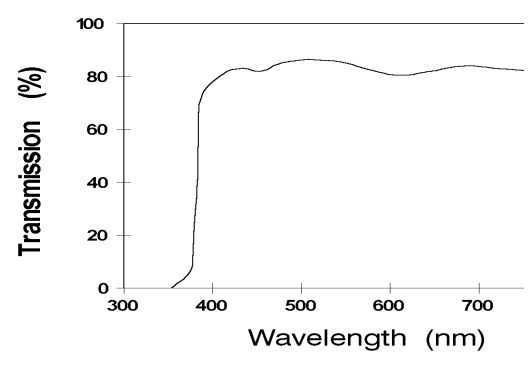

Fig. 5. Transmittance spectra of $\mathrm{ZnO}$ :Al film $(\mathrm{Al} / \mathrm{Zn}=0.9$ at.\%) as a function of the wavelength for film thickness of about $400 \mathrm{~nm}$.

The transmittance characteristics for $\mathrm{ZnO}$ :Al film was measured in the visible range (300 - $800 \mathrm{~nm}$ wavelength) and the results is shown in fig. 5 . This film was deposited at the substrate temperature of $300{ }^{\circ} \mathrm{C}$, whereas the sputter gas pressure and the dc power were maintained constant. A high transmittance in the visible range was obtained in the $\mathrm{ZnO}$ :Al films. The marked decrease of transmittance at wavelengths shorter than about $400 \mathrm{~nm}$, and the average transmission over the $400-800$ nm range exceeds $80 \%$. The optical transmission of $\mathrm{ZnO}$ films depend on the deposition temperature [15]. The increase of transmittance may be attributed to the decrease of film thickness, increase of structural homogenity and crystallinity of the films.

\section{CONCLUSIONS}

It was determined that the dc magnetron sputtering technique is a good method to deposit transparent conductive $\mathrm{ZnO}$ thin films. Transparent, high electrical conductivity, c-axis, highly oriented $\mathrm{ZnO}$ :Al thin films were grown on glass substrates by dc magnetron sputtering at different substrate temperatures. The degree of crystallinity, optical transmission, and electrical properties is strongly dependent on the substrate temperature. Films grown on $300{ }^{\circ} \mathrm{C}$ substrates showed a high conductivity value of $0.2 \times 10^{2} \Omega^{-1} \mathrm{~cm}^{-1}$. 
Doping with aluminium significantly increases the conductivity of these films by about five orders of magnitude, and a transmittance of about $85 \%$ in the visible range.

\section{ACKNOWLEDGEMENTS}

The authors wish to acknowledge B. Siswanto and Yunanto for their technical assistance in the experiments. This work was partially supported by a RUT V from the Ministry of Research and Technology of Indonesia.

\section{REFERENCES}

1. Frank T.J. Smith, Appl. Phys. Lett. 43, 1108 (1983)

2. Frans C.M. Van de Pol, Ceramic Bulletin, 69, 1959 (1990)

3. M. Miura, Jpn. J. Appl. Phys. 21, 264 (1982)

4. S.J. Chang, Y.K. Su, and Y.P. Shei, J. Vac. Sci. Technol., A13, 385 (1995)

5. S. Tanaka, K. Takahashi, T. Sekiguchi, K. Sumino, and J. Tanaka, J. Appl. Phys., 77, 4021 (1995)

6. J. Fan, and R. Freer, J. Appl. Phys., 77, 4795 (1995)
7. T. Itoh, and T. Suga, Appl. Phys. Lett. 64, 37 (1994)

8. B.R. Jooste, H.J. Viljoen, N.F. J van Rens-burg, J. Vac. Sci. Technol. A14, 714 (1996)

9. M.K. Puchert, P.Y. Timbrell, and R.N. Lamb, J. Vac. Sci. Technol., A14, 2220 (1996)

10. K. Tabuchi, W.W. Wenas, A. Yamada, M. Konagai, and K. Takahashi, Jpn. J. Appl. Phys., 32, 3764 (1993)

11. T. Minami, T. Kakumu, and S. Tahata, J. Vac. Sci. Technol. A14, 1704 (1996)

12. J. Saeed, and P. O’Brien, Thin Solid Films, 271, 35 (1995)

13. F.S. Mahmood, R.D. Gould, A.K. Hassan, and H.M. Salih, Thin Solid Films, 270, 376 (1995)

14. Y.E. Lee, J.B. Lee, Y.J. Kim, H.K. Yang, J.C. Park, and H.J. Kim, J. Vac. Sci. Technol. A14, 1943 (1996)

15. M. Krunks, and E. Mellikov, Thin Solid Films, 270, 33 (1995)

16. J. Ma, F. Ji, H. Ma, and S. Li, Thin Solid Films, 279, 213 (1995)

17. K. Wasa and S. Hayakawa, Handbook of Sputter Deposition Technology, Noyes Publications, New Jersey (1992). 